\title{
Toxicity Test for the Extract of Symbiont Bacteria Bacillus sp. as Anti-bacteria
}

\author{
Slamet Isworo ${ }^{*}$ (D) and Sulistyani² \\ ${ }^{1}$ Environmental Health Department, Faculty of Health Science, Dian Nuswantoro University, Semarang, \\ Indonesia. ${ }^{2}$ Environmental Health Department, Faculty of Public Health, Diponegoro University, Semarang, \\ Indonesia.
}

\begin{abstract}
Increased antibiotic resistance spurs exploration of bioactive compounds as new antibiotic alternatives. Bacillus sp. is a symbiont bacterium which is a marine microorganism that has the potential to produce new bioactive compounds that can be developed as new antibiotics. This research is an experimental study aimed at identifying bioactive compounds by thin layer chromatography methods and testing the activity of bioactive compounds by probit analysis EPA probit analysis program version 1.5. in Artemia salina Leach. Bioactive compounds identified were compounded from the alkaloid group with the category of highly toxic several-irritating base on the EPA toxicity category and the highly hazardous base on The WHO toxicity category based on the environmental protection agency probit analysis program used for calculating $L C / E C$ value of $L C C_{50}=169,520 \mathrm{~g} / \mathrm{l}$. Symbiont Bacillus sp. produce secondary metabolites in the form of bioactive which have the ability as anti-bacteria. As a new antibiotic alternative to overcome resistance, especially in methicillin-resistant bacteria

Keyword: Bacillus sp., Artemia salina Leach, secondary metabolites, bioactive, highly toxic several-irritating, symbiont, highly hazardous, brine shrimp lethality toxicity.
\end{abstract}

\footnotetext{
*Correspondence: slamet.isworo@dsn.dinus.ac.id

(Received: 03 September 2019; accepted: 28 September 2019)

Citation: Slamet Isworo and Sulistyani, Toxicity Test for the Extract of Symbiont Bacteria Bacillus sp. as Anti-bacteria, J Pure Appl Microbiol., 2019; 13(4):1977-1984. https://doi.org/10.22207/JPAM.13.4.09

C The Author(s) 2019. Open Access. This article is distributed under the terms of the Creative Commons Attribution 4.0 International License which permits unrestricted use, sharing, distribution, and reproduction in any medium, provided you give appropriate credit to the original author(s) and the source, provide a link to the Creative Commons license, and indicate if changes were made.
} 


\section{INTRODUCTION}

Indonesia as a maritime country has abundant biodiversity, especially the marine wealth that is both microorganisms and macroorganism. Macro-rich marine assets include various types of marine flora and fauna, while micro-species are various types of algae, yeast and marine bacteria, which have the potential to develop natural product materials ${ }^{1}$. As biotechnology develops, the utilization of marine riches and marine biodiversity as natural product ingredients ${ }^{1}$ starts to be utilized in the field of pharmacology, especially in the field of finding new alternative antibiotics derived from the results of the isolation of secondary metabolites (bioactive compounds) produced by marine organism associations. Research on secondary metabolite compounds produced by symbiont bacteria associated with soft corals in the sea is the development of research in alternative new antibiotic discoveries. The isolated compounds were then tested for toxicity, to determine the effectiveness of secondary metabolites (bioactive) against pathogenic bacteria ${ }^{2}$. Toxicity tests for secondary metabolites can be tested by various methods, among others by the Brine Shirmps Lethality Test Method. Brine Shrimp Lethality Test Method is a method for determining the toxic nature of a secondary metabolite compound produced by certain organisms in the Arthemia salina test organism, if the secondary metabolite compound has biological activity, then the secondary metabolite is said to be a new alternative antibiotic bioactive compound ${ }^{3}$.

The symbiont bacteria are a community of bacteria that live in association with other biota, especially soft corals, hard corals and sponges in a variety of interaction patterns. In accordance with the characteristics of the two, the specific interactions between symbiont and host allow the potential for the same secondary metabolite product to occur, therefore drug development from bioactive compounds produced by soft corals, hard corals and sponges is more likely to be isolated from symbiont bacteria. Marine symbiont bacteria that are symbiotic with soft corals are alternatives that are more likely to be developed as sources of bioactive substances. Bacteriological research is easier and cheaper to carry out than research on high-level biota, this is because the breeding and isolation of marine bacteria are easier than isolation from high-level biota sources ${ }^{4}$.

Pressure conditions in the marine environment are greater than the terrestrial environment causing marine organisms to be more adaptive to extreme environments, so it is possible that the metabolite compounds produced will be better ${ }^{5}$. The various studies report on symbiont bacteria that live in a symbiotic interaction with soft corals and able to produce certain anti-bacterial compounds, namely the discovery of bacteria that live in symbiosis with hard corals, soft corals and sponges have the ability to inhibit Escherichia coli, Streptococcus aureus, Streptococcus sp. and Aeromonas hidrophyla ${ }^{6}$.

The soft coral Sarcophyton $s p$. is one type of soft coral that produces natural chemical compounds and is known as a natural product. These natural chemical compounds have the potential as a source of natural medicine. Active chemical compounds found in soft corals Sarcophyton sp. exhibits antibacterial, antifungal, antitumor, neurotoxic, and anti-inflammatory activities that are beneficial to the pharmaceutical industry ${ }^{7}$. This form of symbiotic interaction can stimulate the formation of bioactive compounds in symbiont organisms. Bioactive compounds from the marine environment have many unique chemical structures not found in terrestrial environments, in addition, bioactive compounds from the marine environment are potential agents as new antibiotic drug ingredients. Bacteria Bacillus $s p$. is one of the microorganisms that live in symbiosis with soft coral Sarcophyton $s p$. and several species of Bacillus sp. known to be active against Methicillin-Resistant Staphylococcus aureus and resistant to Vancomycin-resistant Enterococcus and produce bacteriocin - type antibiotics ${ }^{8}$. In connection with this, it is necessary to conduct research on the symbiont bacteria Bacillus $s p$. from soft coral Sarcophyton $s p$., to determine the level of toxicity of secondary metabolites that it produces against the Artemia salina Leach test animals with the brine shrimp lethality test methods ${ }^{9}$.

\section{MATERIALS AND METHODS}

Toxicity test for bioactive extract of Bacillus sp.

a) Experimental research with a post 
test-only control group design approach ${ }^{10}$, The aim of this study was to examine the potential toxicity of extracts of Bacillus sp. against Artemia salina Leach larvae. Potential toxicity of extracts of Bacillus sp. on Artemia salina Leach larvae was declared toxic if the $L C$ value $<501000 \mu \mathrm{g} / \mathrm{ml}$ after an acute toxicity test was performed ${ }^{11}$.

b) Standard mortality indicator for Artemia salina Leach larvae if Artemia salina Leach larvae do not show movement for several seconds after observation.

c) Bacillus sp. bacteria used is a collection of the Faculty of Public Health, University of Diponegoro which is a symbiont soft coral bacterium

Identification of bioactive compounds

Identification of Bioactive Compounds by separating the chemical content of the most active fractions from the partition results is done by thin layer chromatography ${ }^{12}$.

Antimicrobial activity testing

Anti-microbial activity was measured in vitro to determine the potential of antibacterial substances and the sensitivity of a bacterium to the concentration of the test material used, then analyzed by probit analysis of the EPA Probit Analysis Program version 1.5 (Used for calculating $L C / E C$ values $)^{13}$.

\section{RESULTS}

Based on research conducted to obtain data as follows:

\section{Brine shrimp lethality toxicity test ${ }^{14}$}

The number of Artemia salina Leach larvae mortality in each test tube at various concentrations of extracts of Bacillus sp. (Table 1 ). Observation results show different effects on the death of Artemia salina leach larvae, as follows:

The number of Artemia salina Leach larvae in each test tube is 30 so that the total number of Artemia salina Leach larvae used is 180 larvae, carried out with 3 replications. The total number of Artemia salina Leach larvae that died in each treatment tube was counted, while the average death of Artemia salina Leach was obtained by dividing the total larvae mortality at each concentration by the number of replications performed. Then the percentage of larvae deaths were calculated from the average death at each concentration.

Toxicity Test Results of Bacillus sp. extract against Artemia salina leach based on the EPA Probit analysis program use for caculating $L C / E C$ Values Version 1.5, as follows (Table 2)

1. Extract of Bacillus sp. with a concentration of 0 ppm in 10 Artemia salina Leach test animals, there is 1 Artemia salina Leach test animal that responds (dies), with proportion responding = $0.0300(3 \%)$.

2. Extract of Bacillus sp. with a concentration of 10 ppm in 10 Artemia salina Leach test animals, there are 2 Artemia salina Leach test animals that respond (die), with proportion responding = $0.2000(20 \%)$

3. Extract of Bacillus sp. with a concentration of $100 \mathrm{ppm}$ in 10 Artemia salina Leach test animals, there were 4 Arthemia salina Leach test animals that responded (died), with proportion responding

Table 1. Test Results for the Brine Shrimp Lethality Test extract of Bacillus sp. in Artemia salina leach larvae at 48 hours

\begin{tabular}{|c|c|c|c|c|c|c|c|c|c|c|}
\hline \multirow[t]{2}{*}{ No. } & \multirow[t]{2}{*}{ Concen. } & \multicolumn{2}{|c|}{ U1 } & \multicolumn{2}{|c|}{ U2 } & \multicolumn{2}{|c|}{ U3 } & \multicolumn{2}{|c|}{ Average } & \multirow[t]{2}{*}{$\%$} \\
\hline & & + & - & + & - & + & - & + & - & \\
\hline 1 & 1000 ppm & & 10 & & 10 & & 10 & 0 & 10 & $100 \%$ \\
\hline 2 & 500 ppm & & 10 & & 10 & & 10 & 0 & 10 & $100 \%$ \\
\hline 3 & 250 ppm & 1 & 9 & 5 & 5 & 5 & 5 & 3,67 & 6,33 & $63 \%$ \\
\hline 4 & 100 ppm & 7 & 3 & 6 & 4 & 4 & 6 & 5,56 & 4,33 & $43 \%$ \\
\hline 5 & 10 ppm & 4 & 6 & 10 & & 10 & & 8 & 2 & $20 \%$ \\
\hline 6 & Control & 10 & & 10 & & 9 & 1 & 10 & 0,33 & $0 \%$ \\
\hline
\end{tabular}

\begin{tabular}{ccc}
\hline \multicolumn{2}{l}{ Information: } & \\
+ & $:$ & Life \\
- & $:$ & Dead \\
$\%$ & $:$ & Percentage
\end{tabular}

Journal of Pure and Applied Microbiology 
Table 2. Probit Test Toxicity Test Extract of Bacillus sp. against Artemia salina Leach

\begin{tabular}{|c|c|c|c|c|c|}
\hline & & & Prop & tion & \\
\hline Observed & & & Res! & nding & Predicted \\
\hline Number & Numb & & $\begin{array}{l}\text { Proportion } \\
\text { responding }\end{array}$ & $\begin{array}{l}\text { Adjusted for } \\
\text { control }\end{array}$ & $\begin{array}{l}\text { Proportion } \\
\text { responding }\end{array}$ \\
\hline Control & 10 & 0 & 0.003 & 0 & 0.1241 \\
\hline 10,000 & 10 & 2 & 0.2 & 0.0866 & 0.0001 \\
\hline 100,000 & 10 & 4 & 0.533 & 0.3526 & 0.2365 \\
\hline 250,000 & 10 & 6 & 0.567 & 0.5056 & 0.7013 \\
\hline 500,000 & 10 & 8 & 1,000 & 1.00 & 0.9293 \\
\hline $1,000,000$ & 10 & 10 & 1,000 & 1.00 & 0.9921 \\
\hline Chi - Square for & neteroge & neity (ca & culated) & $=3.24$ & \\
\hline Chi - Square for & neteroge & heity (tal & ular value at 0. & levels) $=7.815$ & \\
\hline & $\mathrm{Mu}$ & & & $=2.229$ & \\
\hline & Sigma & & & $=0.31 \mathrm{c}$ & \\
\hline Parameter & & timate & Std. Err. & 95\% Confiden & mits \\
\hline Intercept & -1 . & 978474 & 2.543889 & $(-6.964497,3$ & 549) \\
\hline Slope & & 130453 & 1.063219 & $(1.046543,5$ & 363) \\
\hline Spontaneous & & 24136 & 0.073508 & $(-0.019939, \quad 0$ & 211) \\
\hline Response Rate & & & & & \\
\hline
\end{tabular}

$=0.4330(43.3 \%)$

4. Extract of Bacillus sp. with a concentration of 250 ppm in 10 Artemia salina Leach test animals, there were 6 Artemia salina Leach test animals that responded (died), with proportion responding $=0.5670(56.7 \%)$.

5. Extracts of Bacillus sp. with a concentration of 500 ppm in 10 Artemia salina Leach test animals, there are 10 Artemia salina Leach test animals that respond (die), with proportion responding = $1(100 \%)$.

6. Extract of Bacillus sp. with a concentration of 1000 ppm in 10 Arthemia salina Leach test animals, there are 10 Artemia salina Leach test animals that respond (die), with proportion responding $=1(100 \%)$.

Proportion responding is the proportion of test animals that respond to active compounds which are described in terms of a percentage. The higher the proportion of proportion responding, the greater the test animals that die due to the active compounds exposed. Chi-Square for Heterogeneity (calculated) = 3,246 and Chi-Square for Heterogeneity (tabular value at 0.05 levels) = 7,815 so the research is said to be homogeneous because Chi-Square for Heterogeneity (calculated)
$=4,847<$ Chi-Square for heterogeneity (calculated) tabular value at 0.05 level $=7.815$ ). Concentrations of potentially toxic substances in environmental media that cause death after a certain period of exposure are denoted by LC. $L D_{50}$ is a statistic that is derived statistically, to express a single dose of a compound that is thought to be deadly or cause significant toxic effects in $50 \%$ of experimental animals after treatment. $L D_{50}$ is a quantitative benchmark that is often used to express the lethal dose range. In general, the smaller the $L D_{50}$ value, the more toxic the compound is and the greater the $L D_{50}$ value, the lower the toxicity. The results of probit analysis using the EPA Probit Analysis Program Version 1.5 (Used For Calculating LC/EC Values) show LC values of extracts of Bacillus $s p$. is

Table 3. Results of $L C_{50}$ analysis of secondary metabolite compounds extracts of Bacillus sp. against Artemia salina Leach for 48 hours

\begin{tabular}{lccc}
\hline \multicolumn{2}{c}{ Exposure } & \multicolumn{2}{c}{$95 \%$ Confidence } \\
& & \multicolumn{2}{c}{ Limits } \\
\hline Point & Conc & Lower & Upper \\
LC/EC $_{50}$ & 169.52 & 58.337 & 269.048 \\
& & & \\
\hline
\end{tabular}


Table 4. EPA Toxicity Category ${ }^{17}$

\begin{tabular}{|c|c|c|c|c|}
\hline \multirow{2}{*}{$\begin{array}{l}\text { Hazard } \\
\text { Indicator }\end{array}$} & \multicolumn{3}{|c|}{ Toxicity Category } & \multirow[b]{2}{*}{4} \\
\hline & 1 & 2 & 3 & \\
\hline \multirow[t]{2}{*}{ Oral $L D_{50}$} & Up to end including & From 50 thru & From 500 thru & Greater than \\
\hline & 50 mg/kg & 500 mg/kg & 5000 mg/kg & 500 mg/kg \\
\hline \multirow{2}{*}{ Inhalation $L C_{50}$} & Up to end including & From 0,2 thru & From 2 thru & Greater than \\
\hline & $0,2 \mathrm{mg} / \mathrm{L}$ & $2 \mathrm{mg} / \mathrm{L}$ & $20 \mathrm{mg} / \mathrm{L}$ & $20 \mathrm{mg} / \mathrm{L}$ \\
\hline \multirow{2}{*}{ Dermal $L D_{50}$} & Up to end including & From 200 thru & From 2000 thru & Greater than \\
\hline & 200 mg/kg & 2000 mg/kg & 20000 mg/kg & $20000 \mathrm{mg} / \mathrm{Kg}$ \\
\hline Eye Effect & $\begin{array}{l}\text { Corrosive corneal } \\
\text { opacity not reversible } \\
\text { within } 7 \text { days }\end{array}$ & $\begin{array}{l}\text { Corneal opacity } \\
\text { severe irritation } \\
\text { at } 7 \text { days }\end{array}$ & $\begin{array}{l}\text { No corneal opacity } \\
\text { irritation reversible } \\
\text { within } 7 \text { days }\end{array}$ & No irritation \\
\hline Skin effect & Corrosive & & $\begin{array}{l}\text { Moderate irritation } \\
\text { at } 72 \text { hours }\end{array}$ & $\begin{array}{l}\text { Mild or slight } \\
\text { irritation } \\
\text { at } 72 \text { hours }\end{array}$ \\
\hline
\end{tabular}

Source: 40 CFR 156,62

$169,520 \mathrm{~g} / \mathrm{l}$. this refers to the bioactive compounds produced by Bacillus $s p$. categorized as follows:

1. Highly toxic several - dermal irritating according to EPA toxicity category standards ${ }^{15}$.

2. Highly hazardous based on WHO toxicity category ${ }^{16}$.

Output data from the results of probit analysis can be seen in appendix 1 , while group toxicity based on EPA toxicity category, WHO toxicity category and Loomis toxicity category, as follows (Table 4)

Toxicity category 1: Highly toxic; severely irritating.

Toxicity category 2: Moderately toxic; moderately irritating. irritating.

Toxicity category 3: Slightly toxic; slightly

Toxicity category 4: Practically non-toxic; not an irritant.

To assign a signal word, use the highest hazard shown by any of the indicators for the product

Danger - category 1 . In addition, if the product is in Category 1 because of its oral $L D_{50^{\prime}}$ inhalation $L C_{50}$, or Dermal $L D_{50}$, the word "Poison" along with a skull and crossbones will be on the label

$$
\begin{aligned}
& \text { Warning - category } 2 \\
& \text { Caution - category } 3 \text { or } 4 \\
& \text { Identification of dots using thin layer } \\
& \text { chromatography } \\
& \text { Based on the identification results of the }
\end{aligned}
$$
observation point extract of Bacillus $s p$. by Thin Layer Chromatography method, the following results are obtained:

Based on the results of qualitative analysis, secondary metabolites can be identified based on $\mathrm{Rf}$ (retardation factor) values follows:

The extraction toxicity test of Bacillus $s p$. was performed using the Artemia salina Leach

Table 5. WHO toxicity category ${ }^{16}$

\begin{tabular}{lcccc}
\hline \multirow{2}{*}{ Class } & \multicolumn{4}{c}{ LD 50 for the rate $(\mathrm{mg} / \mathrm{kg}$ body wight) } \\
\hline & \multicolumn{4}{c}{ Oral } \\
\cline { 2 - 5 } & Solid & Liqiud & Solid & Liqiud \\
\hline 1a. Extremely hazardous & 5 or less & 20 or less & 10 or less & 40 or less \\
1b. Highy hazardous & May-50 & $20-200$ & $10-100$ & $40-400$ \\
II. Moderateely hazardous & $50-500$ & $200-2000$ & $100-1000$ & $400-4000$ \\
III. Slightly hazardous & over'500 & over '2000 & over'1000 & over '4000
\end{tabular}


test using the Brine Shrimp Lethality method. Test of a bioactive compound is stated to have the acute toxic ability if it is able to kill $50 \%$ or more of the test animal population in a short interval of time. Based on research results that the bioactive compounds produced are alkaloids with $L C_{50}=169,520$ (concentration $=\mathrm{g} / \mathrm{I}$ ) based on the EPA probit analysis program version 1.5 - used for calculating $L C / E C$ values). The bioactive compounds are categorized as highly toxic several - irritating (EPA toxicity category) and highly hazardous (WHO toxicity category) ${ }^{17}$. The method of identification of bioactive compounds uses the ultra violet ray irradiation method with a wavelength of $254 \mathrm{~nm}$ and the thin layer chromatography method. The identification results show bioactive compounds with $R_{f}$ value $=0.872$ -
0.975, chromatogram dot brown color, bioactive compounds bound to polar compounds. Criteria for these compounds are included in the category of alkaloids ${ }^{12}$.

Toxicity test using the brine shrimp letality test with Artemia salina Leach test animals. This method was chosen because it is easy to implement, does not require a large cost, can be done in a short time and is easy to analyze. Artemia salina Leach is one of the widely used test animals because Artemia salina Leach has a short life cycle, has the ability to adapt to high salinity and extreme temperatures, has a short life cycle, high adaptability to extreme environmental conditions, small body size and body organs which is simple and has a simple cell wall ${ }^{18}$. Exposure to toxicity of bioactive compounds alkaloids to the

Table 6. Identification of nodes using Thin Layer Chromatography ${ }^{12}$

\begin{tabular}{|c|c|c|c|c|}
\hline No & Chromatography Thin Layer Samples & Rf-value & Staining & UV $235 \mathrm{~nm}$ \\
\hline 1 & $\begin{array}{l}\text { Thin Layer Chromatography } 1 \\
\text { The Bacillus sp. extract is bottled without } \\
\text { concentrating with chloroform eluent }\end{array}$ & Negative & Negative & Negative \\
\hline 2 & $\begin{array}{l}\text { Thin Layer Chromatography } 2 \\
\text { The Bacillus sp. extract is bottled by } \\
\text { concentrating with chloroform eluent }\end{array}$ & Negative & Chocolate & Positive \\
\hline 3 & $\begin{array}{l}\text { Thin Layer Chromatography } 3 \\
\text { The Bacillus sp. extract was concentrated } \\
\text { dissolve in ether bottled without } \\
\text { concentration with chloroform eluent } \\
\text { without saturation }\end{array}$ & 0.972 & Chocolate & Positive \\
\hline 4 & $\begin{array}{l}\text { Thin Layer Chromatography } 4 \\
\text { The Bacillus sp. extract concentrated } \\
\text { dissolved in acetone bottled without } \\
\text { concentrating with chloroform eluent } \\
\text { without saturation }\end{array}$ & 0.9 & Chocolate & Positive \\
\hline 5 & $\begin{array}{l}\text { Thin Layer Chromatography } 5 \\
\text { Extract of Bacillus sp. concentrated dissolved } \\
\text { in hexan bottled without concentrating } \\
\text { with chloroform eluent without saturation }\end{array}$ & 0.875 & Chocolate & Positive \\
\hline 6 & $\begin{array}{l}\text { Thin Layer Chromatography } 6 \\
\text { The Extract of Bacillus sp. concentrated } \\
\text { dissolved in ether bottled without } \\
\text { concentrating with chloroform } \\
\text { eluent without saturation }\end{array}$ & 0.91 & Chocolate & Positive \\
\hline 7 & $\begin{array}{l}\text { Thin Layer Chromatography } 7 \\
\text { The extract of Bacillus sp. concentrated } \\
\text { dissolved it in aceton is bottled without } \\
\text { concentrated with chloroform eluents } \\
\text { without saturation }\end{array}$ & 0.9 & Chocolate & Positive \\
\hline
\end{tabular}


Table 7. Secondary Metabolite Screening Results of Bacillus sp. with thin-layer chromatography ${ }^{12}$

\begin{tabular}{|c|c|c|c|c|c|c|}
\hline \multirow[t]{3}{*}{ No. } & \multirow{3}{*}{$\begin{array}{c}\text { Type } \\
\text { Identification }\end{array}$} & \multirow{3}{*}{$\begin{array}{l}\text { Value (Rf) } \\
\text { Retardation } \\
\text { factor value }\end{array}$} & \multicolumn{4}{|c|}{ Chromatogram Color } \\
\hline & & & Reactor & UV & $\mathrm{nm}$ & DPPH \\
\hline & & & & before & $\overline{\text { after }}$ & method \\
\hline \multirow[t]{2}{*}{1} & Alkaloids & 0.8 & Brown & - & - & Yellow \\
\hline & & 0.87 & & $\begin{array}{l}\text { Light blue } \\
\text { (flouresens) }\end{array}$ & $\begin{array}{l}\text { Light blue } \\
\text { (flouresens) }\end{array}$ & \\
\hline \multirow[t]{3}{*}{2} & Flavonoids & 0.13 & Yellow Brown & - & - & Yellow \\
\hline & & 0.72 & Yellow Brown & - & - & Yellow \\
\hline & & 0.78 & & $\begin{array}{c}\text { Light blue } \\
\text { (flouresens) }\end{array}$ & $\begin{array}{c}\text { Blue } \\
\text { (flouresens) }\end{array}$ & \\
\hline \multirow[t]{2}{*}{3} & Polyfenol & 0.41 & Black & - & - & - \\
\hline & & 0.84 & & $\begin{array}{l}\text { Light blue } \\
\text { (flouresens) }\end{array}$ & - & - \\
\hline \multirow[t]{5}{*}{4} & $\begin{array}{l}\text { Terpenoid/ } \\
\text { Steroid }\end{array}$ & 0.06 & Blackish purple & $\begin{array}{c}\text { Light blue } \\
\text { (flouresens) }\end{array}$ & - & - \\
\hline & & 0.16 & Reddish purple & - & - & - \\
\hline & & 0.24 & Dark purple & $\begin{array}{c}\text { Light blue } \\
\text { (flouresens) }\end{array}$ & - & - \\
\hline & & 0.37 & Purple & $\begin{array}{l}\text { Light blue } \\
\text { (flouresens) }\end{array}$ & - & - \\
\hline & & 0.74 & Purple & - & - & - \\
\hline
\end{tabular}

exoskeleton wall Artemia salina causes cell wall damage Artemia salina Leach $^{19}$. Artemia Salina Leach is an osmoregulator type organism so that Artemia salina Leach will continue to ingest the surrounding media both toxic and non-toxic. with this osmoregulation system, alkaloids as secondary matabolites (bioactive) produced by Bacillus $s p$. in the Brine Shrimp Letality Test are toxic and can easily enter the body of Artemia salina Leach and cause death ${ }^{20}$. Alkaloids have the potential for acute toxicity and can cause larval death of Artemia salina Leach. The mechanism of larval death is related to the function of alkaloid compounds which can inhibit the eating power of larvae (antifeedants) which are stomach poisoning ${ }^{21}$. Bioactive components alkaloids cause also disruption of enzymatic function. Enzymes cannot work because of inhibition both competitive and non-competitive by alkaloids, this causes inhibition of metabolic processes and cellular respiration, causing death of Arthemia salina Leach ${ }^{17}$.

\section{CONCLUSION}

Extract of the symbiont Bacillus sp. which is associated with rarely soft produce biocative secondary metabolites which have the ability as anti-bacteria. The resulting bioactives have the potential as an alternative alternative to new antibiotics in overcoming antibiotic resistance, so that further research is needed, especially in the development of research on the scale of the application of alkaloids.

\section{ACKNOWLEDGMENTS}

The researcher would like to thank Dr. Sulistyani and the staff of the Integrated Laboratory of Diponegoro University in Semarang so that this research can run well.

\section{AUTHORS' CONTRIBUTION}

This research was conducted in collaboration between the two authors namely $\mathrm{SI}$ and $\mathrm{S}$. The SI writer conducted the research design, analyzing the results of research, writing a draft of the initial script. Authors SI and S manage 
the research analysis. Author $\mathrm{S}$ manages the search literature and makes final draft corrections. Both authors have read and agreed to the final draft of this article.

\section{CONFLICT OF INTEREST} conflict of interest.

The authors declare that there is no

\section{FUNDING}

None.

\section{AVAILABILITY OF DATA}

All datasets generated or analyzed during this study are included in the manuscript.

\section{ETHICS STATEMENT}

Not applicable.

\section{REFERENCES}

1. Faulkner DJ. Marine natural products. Natural Product Reports, 2001; 18(1): 1R-49R. https://doi.org/10.1039/ b006897g

2. Bull AT, Stach JEM. Marine actinobacteria: new opportunities for natural product search and discovery. Trends in Microbiology, 2007; 15(11): 491-9. https:// doi.org/10.1016/j.tim.2007.10.004

3. Valentin BB, Vinod V, Beulah MC. Biopotential of secondary metabolites isolated from marine sponge Dendrilla nigra. Asian Pacific Journal of Tropical Disease, 2011; 1(4): 299-303. https://doi. org/10.1016/S2222-1808(11)60071-6

4. Li Z. Advances in marine microbial symbionts in the China Sea and related pharmaceutical metabolites. Marine Drugs, 2009; 7(2): 113-29. https://doi. org/10.3390/md7020113

5. Nagano $Y$, Nagahama T. Fungal diversity in deepsea extreme environments. Fungal Ecology, 2012; 5(4): 463-71. https://doi.org/10.1016/j. funeco.2012.01.004

6. Levinton JS, Levinton JS. Marine biology: function, biodiversity, ecology. Vol. 420. Oxford University Press New York; 1995.

7. Kobayashi M, Hirase T. Marine terpenes and terpenoids. $\mathrm{XI}$.: Structures of new dihydrofuranocembranoids isolated from a Sarcophyton sp. soft coral of Okinawa. Chemical and Pharmaceutical Bulletin. 1990; 38(9): 2442-5. https://doi.org/10.1248/cpb.38.2442

8. Ivanova EP, Vysotskii MV, Svetashev VI, Nedashkovskaya Ol, Gorshkova NM, Mikhailov V V, et al. Characterization of Bacillus strains of marine origin. International Microbiology, 1999; 2(4): 267-71.
9. Stirling G, Wilsey B. Empirical relationships between species richness, evenness, and proportional diversity. The American Naturalist, 2001; 158(3): 286-99. https://doi.org/10.1086/321317

10. Campbell DT, Stanley JC. The post test-only control group design. Experimental and quasi-experimental designs for research Chicago; Rand Mcnally College Publishing Co., 1996; 25-31.

11. Aziz MA, Alam AS, Ema AA, Akter M, Chowdhury MMH. Analysis of secondary metabolites, antibacterial, brine shrimp lethality \& larvicidal potentiality of Microcos paniculata fruits. IOSR J Pharm. Biol. Sci., 2014; 9(3): 50-8. https://doi.org/10.9790/3008-09355058

12. Poole CF. Thin-layer chromatography: challenges and opportunities. Journal of Chromatography A., 2003; 1000(1-2): 963-84. https://doi.org/10.1016/S00219673(03)00435-7

13. Ti ler T, Er en NK. Abamectin in the aquatic environment. Ecotoxicology, 2006; 15(6): 495-502. https://doi. org/10.1007/s10646-006-0085-1

14. Selvin J, Lipton AP. Biopotentials of secondary metabolites isolated from marine sponges. Hydrobiologia, 2004; 513(1-3): 231-8. https://doi. org/10.1023/B:hydr.0000018183.92410.21

15. Judson RS, Martin MT, Egeghy P, Gangwal S, Reif DM, Kothiya $\mathrm{P}$, et al. Aggregating data for computational toxicology applications: the US Environmental Protection Agency (EPA) aggregated computational toxicology resource (ACToR) system. International Journal of Molecular Sciences, 2012; 13(2): 1805-31. https://doi.org/10.3390/ijms13021805

16. Organization WH. The WHO recommended classification of pesticides by hazard and guidelines to classification 2009. 2010;

17. Kildgaard S, Mansson M, Dosen I, Klitgaard A, Frisvad $\mathrm{J}$, Larsen $\mathrm{T}$, et al. Accurate dereplication of bioactive secondary metabolites from marine-derived fungi by UHPLC-DAD-QTOFMS and a MS/HRMS library. Marine Drugs, 2014; 12(6): 3681-705. https://doi. org $/ 10.3390 /$ md12063681

18. Morris JE, Afzelius BA. The structure of the shell and outer membranes in encysted Artemia salina embryos during cryptobiosis and development. Journal of Ultrastructure Research. 1967; 20(3-4): 244-59. https://doi.org/10.1016/S0022-5320(67)90285-7

19. Charmantier GUY. Ontogeny of osmoregulation in crustaceans: a review. Invertebrate Reproduction \& Development, 1998; 33(2-3): 177-90. https://doi.or $\mathrm{g} / 10.1080 / 07924259.1998 .9652630$

20. Kavitha A, Prabhakar P, Vijayalakshmi M, Venkateswarlu Y. Production of bioactive metabolites by Nocardia levis MK VL_113. Letters in Applied Microbiology. 2009; 49(4): 484-90. https://doi.org/10.1111/j.1472765X.2009.02697.x

21. Bhakuni DS, Rawat DS. Bioactive marine natural products. Springer Science \& Business Media; 2006. 